\title{
Comparison of composts quality prepared by wide range of organic wastes
}

\author{
Al-Barakah Fahad N. I. \\ Soil Science Department, College of Food and Agriculture Sciences, King Saud University, P.O. Box, 2460, Riyadh, 11451, Saudi \\ Arabia. \\ *Corresponding author. E-mail: barakah@ksu.edu.sa
}

Accepted $18^{\text {th }}$ November, 2019.

\begin{abstract}
Composting has become progressively a popular way and suitable option for recycling the different organic wastes with economic and environmental profits. However, the design of composting systems for farmers is limited due to the low information on the basic concepts of the composting process and how manure characteristics can influence its performance. The present paper summarized the factors affecting the quality of composts produced by using different manures as organic activator. Special attention has been paid to the relevance of $\mathrm{pH}$; Electrical conductivity EC temperature; $\mathrm{CO}_{2}$ concentration; organic carbon (\%); $\mathrm{NH}_{4}(\mathrm{ppm}) ; \mathrm{NO}_{3}(\mathrm{ppm}) ; \mathrm{C}: \mathrm{N}$ ratio; changes in total macro and micro-nutrients and oxygen levels during composting process and the necessity of standardizing the maturity indices due to their great importance amongst compost quality criteria. Microbiological changes during composting process i.e., Total counts of bacterial, Mesophilic and Thermophilic aerobic cellulose decomposer were also considered. Results revealed that a negative correlation was found between temperatures and composting time. Agricultural waste which was treated with $10 \%$ poultry manure showed rapid degradation than the two other manures and recorded the least bacterial counts, while the treatment of agricultural waste $+10 \%$ mixture of camel and sheep manure as organic activator gave the highest bacterial counts and higher EC than either treated with cow or poultry manure. Finally, all these parameters are considered as a good indicator for the end of the biodegradation phase in which the compost achieves maturity.
\end{abstract}

Keywords: Composting, organic wastes, bacterial counts.

\section{INTRODUCTION}

One of the most important ways to achieve the goals of sustainable agriculture is to extend the application of bioorganic farming systems. Bioorganic farming systems have low cost and eco-friendly inputs that have remarkable potential for providing nutrients which can reduce the chemical fertilizer dose by 25 to 50 percent (Vance, 1997). After harvesting the economic part, a great amount of crop residues remain unused and it creates environmental risks. These large quantities of bio residues are potentially nutritious and may be utilized for the production of valued compost (Zakarya et al., 2018).

Composting of animal manures cannot be considered a new technology. It has been traditionally carried out by farmers after manure collection for better handling, transport and management. Frequently the wastes were mounded up with little regard to control the process conditions (aeration, temperature, ammonia loss, etc.) and rudimentary methodology. Huge amounts of organic wastes, i.e., bio solids, animal manures and household wastes, are produced in Saudi Arabia. The suitable option for recycling these wastes is to convert to compost. Efficient composting will overcome the cost of chemical fertilizers with economic and environmental profits. The application of compost not only offers extra organic carbon and nutrients but also improves the soil physical and chemical properties (Yadav et al., 2000; Bhandari et al., 2002). Thus, the application of inorganic fertilizers with organic manure would have a better effect 
Table 1. Chemical properties of raw wastes used in the composting process.

\begin{tabular}{lccc}
\hline Physio-chemical properties & Palm trees waste & Wheat straw & Shoots of vegetable crops \\
\hline $\mathrm{pH}$ & 8.19 & 8.27 & 8.32 \\
$\mathrm{EC}\left(\mathrm{dSm}^{-1}\right)$ & 0.93 & 1.23 & 0.86 \\
Organic matter \% & 89.90 & 94.19 & 81.45 \\
Organic carbon \% & 52.14 & 54.63 & 47.24 \\
Total N \% & 0.61 & 0.56 & 0.81 \\
Total P \% & 0.08 & 0.22 & 0.19 \\
Total K\% & 0.17 & 0.19 & 0.11 \\
C/N ratio & 85.48 & 97.55 & 58.32 \\
\hline
\end{tabular}

on soil health, soil organic matter and related soil properties than the application of inorganic fertilizers. However, combined application of inorganic fertilizers with manure may not result in an increase of soil organic carbon (SOC) because organic matter accumulation depends on the net incorporation of organic matter in the soil, which in turn depends on the cropping and management system employed (Dick, 1992; Paustian et al., 1997; Yadav et al., 2000b; Bhandari et al., 2002; Edmeades, 2003; Gutieŕrez-Miceli et al., 2007; Peyvast et al., 2007,: Peyvast et al., 2008a, b, c, d; Olfati et al., 2009; Shabani et al., 2011; Ayyobi et al., 2013; Ayyobi et al., 2014).

Although manures generally slowly decrease the release of SOC content, and there is less convincing indication that long-term manure application has accumulated effects on yield increase (Dawe et al., 1982). The application of manures is generally seen as a key practice for maintaining soil fertility and agricultural sustainability in different cropping systems (Yadav et al., 2000a, b; Bhandari et al., 2002; Regmi et al., 2002; Ladha et al., 2003; Sarkar et al., 2003; Saleque et al., 2004; Yadvinder et al., 2004; Jiang et al., 2006).

Although previous research (Duplessis and MacKenzie, 1983; Richards et al., 1999; Moss et al., 2001; Malik et al., 2006; Khan et al., 2008; Recep İran et al., 2014) discussed the effects of poultry litter, cattle manure, and leonardite on the yield potential of some crops, so far there has been no side-by-side comparison of these organic manures with regard to their effects on quality of compost produced as well as time of composting. Therefore, further research is needed to clarify which organic manures should be chosen to achieve high quality compost. Hence, the present investigation has been undertaken the objective of this study is to determine the effects of three organic materials on the quality of compost produced.

\section{MATERIALS AND METHODS}

\section{Site description}

The field experiments were conducted at the Agriculture
Research Station, College of Food and Agriculture Sciences, King Saud University, Dirab, South of Riyadh region, Saudi Arabia $\left(24.42^{\circ} \mathrm{N}\right.$ latitude and $46.44^{\circ} \mathrm{E}$ Longitudes, Altitude $600 \mathrm{~m}$ ). The region is under arid climate conditions, with high temperatures and truncated rainfall during the summer and low temperatures and little rainfall during the winter.

\section{Collecting and decomposing organic wastes for producing compost}

All available organic materials were collected i.e. crop residues, wheat straw, palm trees wastes, and vegetables wastes. Chemical properties of raw material (wastes) used in preparing compost were determined, results are presented in (Table 1). Three kinds of manure were used in the present study for preparing compost namely; poultry litter, cow manure and a mixture of sheep and camel manures. Chemical properties and nutrients content of the organic materials used in producing compost were monitored according to standard protocols specified by the US Composting Council (TMECC, 2002). Results are presented in Table 2.

All wastes were decomposed separately in layer in three heaps $(25 \times 10 \times 1.5 \mathrm{~m})$ under medium-high temperatures with adequate moisture through the action of microorganisms hasten the process of composting. Calcium carbonate was added by equal dose to the three heaps (at rate of $2 \%$ ). Each layer was also inoculated with a mixture of $1 \times 10^{8}$ Streptomycs aurefaciens, Trichoderma viridie, T. harzianum, Bacillus subtilis, $B$. licheniformis (1 L/ton) as microbial activators to fasting decomposition in all treatments and then moistened. Changes in temperature that occurred during the composting process were determined using thermometer. Water was added to all windrows to readjust the moisture content to 50 to $65 \%$. Every 15 days, composting mass of the three heaps were mechanically turned upside down. During composting process, samples from the surface area and the central parts of the heaps were taken manually after $0,4,8,12$ and 16 weeks, mixed thoroughly and four replicates 
Table 2. Physio-chemical composition and nutrients content of the organic materials used.

\begin{tabular}{lccc}
\hline Physio-chemical properties & Poultry manure & Cow manure & Mixture of sheep and camel manure \\
\hline Organic matter \% & 50.1 & 29.20 & 36.40 \\
Organic carbon \% & 29.06 & 16.94 & 21.11 \\
EC $\left(\mathrm{dS} \mathrm{m}^{-1}\right)$ & 7.36 & 5.95 & 7.19 \\
$\mathrm{pH}$ & 7.81 & 7.97 & 7.35 \\
Moisture \% & 12.2 & 12.50 & 13.40 \\
Total N \% & 2.05 & 7.97 & 1.35 \\
Total P \% & 1.06 & 0.32 & 0.63 \\
Total K\% & 1.56 & 0.62 & 0.84 \\
\hline
\end{tabular}

were examined for microbiological analyses (total count of aerobic mesophilic bacteria, aerobic mesophilic and thermophilic cellulose-decomposing bacteria) by serial dilution plate count technique (Difco, 1966) and aerobic mesophilic and thermophilic cellulose - decomposing bacteria by using Doubs' cellulose medium procedure (Allen, 1982). Microbial counts were expressed as colony-forming units per gram of compost material (cfu/g). After 0, 30, 60, 90 and 120 days, homogenized samples were manually taken for physically analysis for EC (Chen et al., 1988) and chemically analyzed for organic carbon CO \% (AOAC, 1970), pH, organic matter $\mathrm{OM} \%, \mathrm{C} / \mathrm{N}$ ratio, $\mathrm{NH}_{4}-\mathrm{N}, \mathrm{NO}_{3}-\mathrm{N}$ and total nitrogen by Kjeldahl method (Page et al., 1982), total $\mathrm{P}$ and $\mathrm{K}$ (Cottenie et al., 1982). At the end of decomposing C:N ratio as well as density and toxicity were observed. The values of $\mathrm{C}: \mathrm{N}$ ratio for the three heaps viz., Agricultural wastes $+10 \%$ cow manure; Agricultural wastes $+10 \%$ poultry manure and Agricultural wastes $+10 \%$ mixture of camel and sheep manure were 18.76, 15.68 and 18.65, respectively. Temperature in the central parts of the heaps was determined at intervals and considered satisfactory when a handful of material would wet the hand but not drip (about 60 to $70 \%$ WHC). Water was added if necessary to keep the moisture content inside the heaps at $60 \%$ of the weight through the experiment. During composting process, interaction amongst physical, chemical and biological factors that occurs such as bulk density, porosity, particle size, nutrient content, $\mathrm{C} / \mathrm{N}$ ratio, temperature, $\mathrm{pH}$, moisture and oxygen supply have demonstrated to be key for composting optimization since they determine the optimal conditions for microbial development and organic matter OM degradation (Agnew and Leonard, 2003; Das and Keener, 1997; de Bertoldi et al., 1983; Haug, 1993; Miller, 1992; Richard et al., 2002).

\section{Microbiological and physio-chemical analyses of the decomposing organic wastes}

\section{Microbiological analysis}

Representative samples of the surface and the central parts of the heaps were taken manually after $0,4,8,12$ and 16 weeks, mixed thoroughly and four replicates homogenized samples were examined microbiologically for the total count of aerobic mesophilic bacteria by serial dilution plate count technique (Difco, 1966), aerobic mesophilic and thermophilic cellulose- decomposing bacteria by using Doubs' cellulose medium procedure (Allen, 1982). Microbial counts were expressed as colony forming units per gram of compost material (cfu/g).

\section{Chemical analyses}

The EC was examined according to Chen et al. (1988) and OC \% was followed as described by (AOAC, 1970); $\mathrm{pH}$ was recorded using $\mathrm{pH}$ meter; $\mathrm{OM} \%, \mathrm{C} / \mathrm{N}$ ratio, $\mathrm{NH}_{4}-$ $\mathrm{N}, \mathrm{NO}_{3}-\mathrm{N}$ and total $\mathrm{N}$ by Kjeldahl method were determined according to Page et al. (1982), whereas total $\mathrm{P}$ and $\mathrm{K}$ were determined by the methods described by Cottenie et al. (1982).

\section{RESULTS AND DISCUSSION}

\section{Temperature}

Temperature is an important factor in composting efficiency, due to its influences on the activity and diversity of microorganisms (Finstein et al. 1986). The optimum temperature range for composting is 40 to $65^{\circ} \mathrm{C}$ (de Bertoldi et al., 1983; Zakarya et al., 2018), while temperatures above $55^{\circ} \mathrm{C}$ are required to eliminate pathogenic microorganisms. Changes in temperature that occurred during the composting process are shown in Table 3. In general, the outside temperature was about $37^{\circ} \mathrm{C}$ in the day and $27^{\circ} \mathrm{C}$ in the night. Three periods were distinguished: a phase of latency which correlates to microbial population adapted in the compost conditions, a phase of sudden rise in temperature up to $64^{\circ} \mathrm{C}$ and a phase of cooling in which the temperature decreased progressively and returned to its starting values. At the beginning, the temperature was between $36-38^{\circ} \mathrm{C}$ and start to increase to $40-42^{\circ} \mathrm{C}$ (the end of mesophilic stage). After 6 days, temperature reached 
Table 3. Mean of temperature variations during composting process.

\begin{tabular}{|c|c|c|c|c|c|c|c|c|c|c|}
\hline \multirow[t]{2}{*}{ Treatments } & \multicolumn{10}{|c|}{ Time in weeks } \\
\hline & 0 & 1 & 2 & 3 & 4 & 6 & 8 & 10 & 12 & 16 \\
\hline & \multicolumn{10}{|c|}{ Temperature ${ }^{\circ} \mathrm{C}$} \\
\hline Agricultural wastes $+10 \%$ cow manure & 36 & 53 & 57 & 64 & 63 & 54 & 47 & 42 & 36 & 33 \\
\hline Agricultural wastes $+10 \%$ poultry manure & 38 & 56 & 58 & 65 & 64 & 56 & 48 & 44 & 38 & 35 \\
\hline $\begin{array}{l}\text { Agricultural wastes }+10 \% \text { mixture of camel } \\
\text { and sheep manure }\end{array}$ & 37 & 54 & 56 & 63 & 64 & 55 & 46 & 42 & 37 & 34 \\
\hline
\end{tabular}

Table 4. Microbiological changes during composting of agricultural wastes treated with different rates of organic manure.

\begin{tabular}{|c|c|c|c|c|c|}
\hline \multirow{2}{*}{ Treatments } & \multicolumn{5}{|c|}{ Time in weeks } \\
\hline & 0 & 4 & 8 & 12 & 16 \\
\hline \multicolumn{6}{|l|}{ Total bacterial counts (Counts $\times 10^{7} \mathrm{CFU} / \mathrm{g}$ ) } \\
\hline Agricultural wastes $+10 \%$ cow manure & 34 & 64 & 95 & 85 & 63 \\
\hline Agricultural wastes $+10 \%$ poultry manure & 27 & 76 & 89 & 81 & 48 \\
\hline Agricultural wastes $+10 \%$ mixture of camel and sheep manure & 49 & 99 & 104 & 94 & 77 \\
\hline \multicolumn{6}{|l|}{ Mesophillic aerobic cellulose decomposer (Counts $\times 10^{4} \mathrm{CFU} / \mathrm{g}$ ) } \\
\hline Agricultural wastes $+10 \%$ cow manure & 139 & 32 & 98 & 63 & 54 \\
\hline Agricultural wastes $+10 \%$ poultry manure & 158 & 60 & 117 & 86 & 75 \\
\hline Agricultural wastes $+10 \%$ mixture of camel and sheep manure & 160 & 66 & 128 & 97 & 82 \\
\hline \multicolumn{6}{|l|}{ Thermophillic aerobic cellulose decomposer (Counts $\times 10^{5} \mathrm{CFU} / \mathrm{g}$ ) } \\
\hline Agricultural wastes $+10 \%$ cow manure & 39 & 81 & 102 & 78 & 54 \\
\hline Agricultural wastes $+10 \%$ poultry manure & 38 & 85 & 113 & 69 & 41 \\
\hline Agricultural wastes $+10 \%$ mixture of camel and sheep manure & 41 & 92 & 123 & 86 & 55 \\
\hline
\end{tabular}

$54-56^{\circ} \mathrm{C}$ with little variations till the second week. The maximum values of temperature between $63-65^{\circ} \mathrm{C}$ were found after 3 and 4 weeks. Then the temperature gradually decreased and reached $33-35^{\circ} \mathrm{C}$ by the end of composting. The high temperature inside the heaps is necessary to eliminate pathogenic microorganisms. However, temperature should not exceed $65^{\circ} \mathrm{C}$, as this would harm almost all microorganisms and cause the process to cease. The rising of temperature during composting is mainly due to the activity of microorganisms in the degradation of agricultural wastes. These results are in agreement with the findings of Stentiford (1996), El-Meniawy (2003), Abdel-Aziz and AlBarakah (2005) and Eida (2007). The obtained results revealed that a negative correlation was found between temperatures and composting time, and this was due to decrease in temperature by the end of composting. Generally, the increase in temperature may be also attributed to the suitability of composting conditions $(\mathrm{C} / \mathrm{N}$ ratio, moisture content, aeration, particle size) for microbial and enzymatic activities. On the other hand, the decrease in temperature was attributed to the decrease in microbial and enzymatic activities. This finding is supported by the results of Noguerira et al. (1999).

\section{Microbiological changes}

Table 4 show that total bacterial counts increased gradually and reached its maximum rate after 8 weeks initially, then decreased until the end of the composting period at 16 weeks. These results indicated the importance of mesophilic bacteria at the beginning of composting as they used the readily decomposable constituents of organic wastes. The obtained results are similar with those obtained by Khalil et al. (2001), who demonstrated that bacteria flourish because of their ability to grow rapidly on soluble protein and other readily available substrates and because they are more tolerant to high temperature. They added also that, mesophilic microorganisms are responsible for the initial decomposition of organic materials and the generation of heat responsible for the increase in compost temperature. These sharply decreases in microbial population at the maturity stage, and could be deduced to the diminution of moisture and depletion of organic matter at this later stage of composting process. The treatment of agricultural waste $+10 \%$ mixture of camel and sheep manure gave the highest bacterial counts, while the treatment of agricultural waste $+10 \%$ poultry manure recorded the least one. These 
results are in line with those of Abo-Sedera (1995) and Radwan and Awad (2002). Table 4 shows sharp decrease in counts of mesophilic aerobic cellulose decomposing bacteria at the third week of composting followed by an increase till the end of the composting process. These results indicated the importance of mesophilic aerobic cellulose decomposing bacteria at the beginning of composting as they breakdown cellulytic materials as a part of decomposable constituents of organic wastes. The decrease in mesophilic aerobic cellulose decomposing bacteria after 3 to 4 weeks was due to the high temperature recorded at 63 to $65^{\circ} \mathrm{C}$. These results were in harmony with those obtained by El-Meniawy (2003) and Eida (2007). Counts of thermophilic aerobic cellulose decomposing bacteria in the composted materials showed a marked increase after 4 weeks of composting reaching its maximum counts at the 8 week (Table 4). This also was mainly due to the high temperature of the heap during this period of composting. Thermophilic aerobic cellulose decomposing bacteria, thereafter, decreased with the fall of temperature until the end of the composting period. This decline in numbers could confirmed to the postulates mentioned by Ryckeboer et al. (2003), that during the curing and maturity phase, the cellulose may become inaccessible to enzymatic activity because of low water content or association with protective substrates such as lignin. These results also indicated that changes in temperature of the composted heaps govern the types and development of microorganisms concerned in the decomposition process (Abdel-Aziz and Al-Barakah, 2005; Eida, 2007). In general, aerobic cellulose decomposing bacteria were deferent as type of manure and rend of total bacterial counts.

\section{$\mathrm{pH}$}

In the present study, $\mathrm{pH}$ values of raw materials of the different materials (wastes) used at initial time of composting were slightly alkaline $8.41,8.33$ and 8.48 for the treatments of agricultural wastes $+10 \%$ cow manure; agricultural wastes $+10 \%$ poultry manure and agricultural wastes $+10 \%$ mixture of camel and sheep manure respectively (Table 5). A pH of 6.7 to 9.0 supports good microbial activity during composting (Zakarya et al., 2018). Optimum values are between 5.5 and 8.0 (de Bertoldi et al., 1983; Miller, 1992). Usually, pH is not a key factor for composting since most materials are within this $\mathrm{pH}$ range. However, this factor is very relevant for controlling N-losses by ammonia volatilization, which can be particularly high at $\mathrm{pH}>7.5$. During composting, $\mathrm{pH}$ values gradually decreased due to the formation of organic acids during the metabolism of relatively readily available carbohydrates, consumption of ammonia by microorganisms and as a result of volatilization of free ammonia to the air. Finally, the $\mathrm{pH}$ tended to stabilize due to humus formation with its buffering capacity at the fermentation of composting activity as also mentioned by
Khalil et al. (2001), and Abdel-Aziz and Al-Barakah (2005).

\section{EC}

It was observed that organic activator was higher in EC of agricultural waste treated with $10 \%$ mixture of camel and sheep manure, than either treated with cow or poultry manure at the initial time and during composting process (Table 5). Although a gradual increase in the EC during the composting process of the different treatments was observed, but the EC value did not exceed over the recommended limits. This increase in EC values may be attributed to loss of biomass through the biotransformation of organic materials and also to release some of its content as mineral nutrients. The present results are in line with the results obtained by Abd ElMaksoud et al. (2002) and Abdelhamid et al. (2004), as they reported an increase in EC values during composting process. Furthermore, Lasaridi et al. (2006) suggested that a value of $4.0 \mathrm{dSm}^{-1}$ for $\mathrm{EC}$ is a level considered tolerable by plants whereas values from 6 to $12 \mathrm{dSm}^{-1}$ indicate a toxicity level due to salts for most plants up to the Greek standers.

\section{Dry matter content}

The optimum water content for composting varies with the waste materials in the compost process, but generally it should be at 50 to $60 \%$ (Gajalakshmi and Abbasi, 2008). When the moisture content exceeds $60 \%$, the $\mathrm{O}_{2}$ movement is inhibited and the process tends to become anaerobic (Das and Keener, 1997). During composting a large quantity of water can evaporate, then dry matter content of the different treatments decreased gradually during the whole period of composting (Table 5). The total losses of the dry matter amount recorded 48.76, 49.92 and $47.21 \%$ from the initial amount of the three treatments viz., agricultural wastes $+10 \%$ cow manure; agricultural wastes $+10 \%$ poultry manure and agricultural wastes $+10 \%$ mixture of camel and sheep manure, respectively. These results are in line with those found by Wallace (2003) and Eida (2007). Results also clearly indicates that there is rapid degradation of agricultural waste treated with $10 \%$ poultry manure as organic activator compared to those treated with $10 \%$ of cow manure or $10 \%$ mixture of camel and sheep manure. This may be due to the low $\mathrm{C} / \mathrm{N}$ ratio and availability of nitrogen in poultry manure which increase the microorganism's activity in biodegradation of agricultural waste in the presence of poultry manure as organic activator compared to other two treatments.

\section{Available and total nitrogen}

As shown in Table 6, $\mathrm{NH}_{4}-\mathrm{N}$ was decreased as the result of decomposition process, while $\mathrm{NO}_{3}$ and the percentage 
Table 5. Physicochemical changes during composting of agricultural wastes treated with different organic manures.

\begin{tabular}{|c|c|c|c|c|c|}
\hline \multirow{2}{*}{ Treatments } & \multicolumn{5}{|c|}{ Time in days } \\
\hline & 0 & 30 & 60 & 90 & 120 \\
\hline \multicolumn{6}{|l|}{ Dry matter $(\mathrm{kg})$} \\
\hline 1. Agricultural wastes $+10 \%$ cow manure & 8218 & 5381 & 4844 & 4385 & 4211 \\
\hline 2. Agricultural wastes $+10 \%$ poultry manure & 8011 & 5201 & 4289 & 4023 & 4012 \\
\hline 3. Agricultural wastes $+10 \%$ mixture of camel and sheep manure & 8359 & 5489 & 4987 & 4527 & 4413 \\
\hline \multicolumn{6}{|l|}{$\mathrm{pH}$} \\
\hline 1. Agricultural wastes $+10 \%$ cow manure & 8.41 & 7.51 & 7.43 & 7.31 & 7.27 \\
\hline 2. Agricultural wastes $+10 \%$ poultry manure & 8.33 & 7.39 & 7.30 & 7.15 & 7.11 \\
\hline 3. Agricultural wastes $+10 \%$ mixture of camel and sheep manure & 8.48 & 7.66 & 7.48 & 7.36 & 7.32 \\
\hline \multicolumn{6}{|l|}{$E C\left(d S m^{-1}\right)$} \\
\hline 1. Agricultural wastes $+10 \%$ cow manure & 2.50 & 2.94 & 3.15 & 3.61 & 3.79 \\
\hline 2. Agricultural wastes $+10 \%$ poultry manure & 2.33 & 2.68 & 3.01 & 3.36 & 3.52 \\
\hline 3. Agricultural wastes $+10 \%$ mixture of camel and sheep manure & 3.02 & 3.20 & 3.61 & 3.79 & 3.91 \\
\hline \multicolumn{6}{|l|}{ Organic matter (\%) } \\
\hline 1. Agricultural wastes+ $10 \%$ cow manure & 79.96 & 61.53 & 51.25 & 44.37 & 42.98 \\
\hline 2. Agricultural wastes $+10 \%$ poultry manure & 75.04 & 58.14 & 46.82 & 42.60 & 41.65 \\
\hline 3. Agricultural wastes $+10 \%$ mixture of camel and sheep manure & 87.56 & 63.53 & 54.25 & 47.37 & 46.96 \\
\hline \multicolumn{6}{|l|}{ Organic carbon (\%) } \\
\hline 1. Agricultural wastes $+10 \%$ cow manure & 46.38 & 35.69 & 29.73 & 25.74 & 26.09 \\
\hline 2. Agricultural wastes $+10 \%$ poultry manure & 43.83 & 25.42 & 27.16 & 24.71 & 24.16 \\
\hline 3. Agricultural wastes $+10 \%$ mixture of camel and sheep manure & 50.78 & 36.84 & 31.47 & 27.47 & 27.24 \\
\hline
\end{tabular}

Table 6. Changes in $\mathrm{N}$-forms and $\mathrm{C} / \mathrm{N}$ ratio during composting of agricultural wastes treated with different organic manures.

\begin{tabular}{|c|c|c|c|c|c|}
\hline \multirow{2}{*}{ Treatments } & \multicolumn{5}{|c|}{ Time in days } \\
\hline & 0 & 30 & 60 & 90 & 120 \\
\hline \multicolumn{6}{|l|}{ Total N (\%) } \\
\hline Agricultural wastes $+10 \%$ cow manure & 0.66 & 1.09 & 1.20 & 1.25 & 1.39 \\
\hline Agricultural wastes $+10 \%$ poultry manure & 0.78 & 1.19 & 1.31 & 1.36 & 1.54 \\
\hline Agricultural wastes $+10 \%$ mixture of camel and sheep manure & 0.69 & 1.12 & 1.24 & 1.29 & 1.46 \\
\hline \multicolumn{6}{|l|}{$\mathrm{NH}_{4}(\mathrm{ppm})$} \\
\hline Agricultural wastes $+10 \%$ cow manure & 439 & 269 & 189 & 137 & 130 \\
\hline Agricultural wastes $+10 \%$ poultry manure & 497 & 291 & 221 & 161 & 149 \\
\hline Agricultural wastes $+10 \%$ mixture of camel and sheep manure & 462 & 273 & 231 & 149 & 138 \\
\hline \multicolumn{6}{|l|}{$\mathrm{NO}_{3}(\mathrm{ppm})$} \\
\hline Agricultural wastes $+10 \%$ cow manure & 67 & 372 & 415 & 435 & 452 \\
\hline Agricultural wastes $+10 \%$ poultry manure & 81 & 432 & 467 & 506 & 519 \\
\hline Agricultural wastes $+10 \%$ mixture of camel and sheep manure & 72 & 417 & 434 & 452 & 469 \\
\hline \multicolumn{6}{|l|}{$\mathrm{C} / \mathrm{N}$ ratio } \\
\hline Agricultural wastes $+10 \%$ cow manure & 70.27 & 32.74 & 24.77 & 20.59 & 18.76 \\
\hline Agricultural wastes $+10 \%$ poultry manure & 56.19 & 21.36 & 20.73 & 18.17 & 15.68 \\
\hline Agricultural wastes $+10 \%$ mixture of camel and sheep manure & 73.59 & 32.89 & 24.38 & 21.29 & 18.65 \\
\hline
\end{tabular}


Table 7. Changes in total macro and micro-nutrients during composting of agricultural wastes treated with different organic manures.

\begin{tabular}{|c|c|c|c|c|c|c|c|}
\hline \multirow[b]{2}{*}{ Treatments } & \multicolumn{3}{|c|}{ Macro-nutrients } & \multicolumn{4}{|c|}{ Micro-nutrients } \\
\hline & $\mathbf{N}(\%)$ & $\mathbf{P}(\%)$ & K (\%) & $\begin{array}{c}\mathrm{Fe} \\
\mathrm{ppm}\end{array}$ & $\begin{array}{c}\text { Mn } \\
\text { ppm }\end{array}$ & $\begin{array}{c}\mathrm{Zn} \\
\mathrm{ppm}\end{array}$ & $\begin{array}{c}\mathrm{Cu} \\
\mathrm{ppm}\end{array}$ \\
\hline \multicolumn{8}{|l|}{ Initial } \\
\hline Agricultural wastes $+10 \%$ cow manure & 0.66 & 0.478 & 0.328 & 4358 & 41 & 22 & 18 \\
\hline Agricultural wastes $+10 \%$ poultry manure & 0.78 & 0.597 & 0.419 & 5487 & 64 & 31 & 21 \\
\hline Agricultural wastes $+10 \%$ mixture of camel and sheep manure & 0.69 & 0.605 & 0.412 & 4841 & 58 & 29 & 19 \\
\hline \multicolumn{8}{|l|}{30 days } \\
\hline Agricultural wastes $+10 \%$ cow manure & 1.09 & 0.504 & 0.362 & 5215 & 76 & 31 & 22 \\
\hline Agricultural wastes $+10 \%$ poultry manure & 1.19 & 0.614 & 0.448 & 6176 & 99 & 37 & 28 \\
\hline Agricultural wastes $+10 \%$ mixture of camel and sheep manure & 1.12 & 0.631 & 0.429 & 5694 & 91 & 35 & 26 \\
\hline \multicolumn{8}{|l|}{60 days } \\
\hline Agricultural wastes $+10 \%$ cow manure & 1.20 & 0.516 & 0.417 & 6213 & 84 & 35 & 24 \\
\hline Agricultural wastes $+10 \%$ poultry manure & 1.31 & 0.639 & 0.481 & 6819 & 132 & 41 & 28 \\
\hline Agricultural wastes $+10 \%$ mixture of camel and sheep manure & 1.24 & 0.645 & 0.462 & 6764 & 121 & 46 & 28 \\
\hline \multicolumn{8}{|l|}{90 days } \\
\hline Agricultural wastes $+10 \%$ cow manure & 1.25 & 0.539 & 0.442 & 6956 & 99 & 37 & 27 \\
\hline Agricultural wastes $+10 \%$ poultry manure & 1.36 & 0.685 & 0.517 & 7830 & 139 & 49 & 30 \\
\hline Agricultural wastes $+10 \%$ mixture of camel and sheep manure & 1.29 & 0.678 & 0.489 & 7194 & 132 & 46 & 29 \\
\hline \multicolumn{8}{|l|}{120 days } \\
\hline Agricultural wastes $+10 \%$ cow manure & 1.39 & 0.568 & 0.472 & 6986 & 118 & 41 & 28 \\
\hline Agricultural wastes $+10 \%$ poultry manure & 1.54 & 0.695 & 0.535 & 7938 & 142 & 51 & 31 \\
\hline Agricultural wastes $+10 \%$ mixture of camel and sheep manure & 1.46 & 0.708 & 0.518 & 7695 & 138 & 49 & 30 \\
\hline
\end{tabular}

of total nitrogen were increased in all treatments. The increase in total nitrogen percent may be due to the higher oxidation of non-nitrogenous organic materials and partially to the $\mathrm{N}_{2}$-fixation by non-symbiotic nitrogen fixers as indexed by the increase in organic nitrogen. This indicates that the immobilization of nitrogen taken place during composting conserved the nitrogen from loss.

\section{$\mathrm{C} / \mathrm{N}$ ratio}

The $\mathrm{C} / \mathrm{N}$ ratio is one of the main parameters that describe the composting process. It is often used as an index of composting maturity, despite many pitfalls associated with this approach, but it seems to be a reliable parameter for following the development of the composting process (Khalil et al., 2001). Changes in the ratio of organic carbon to nitrogen during composting of agricultural wastes treated with different organic manure as organic activators are recorded in Table 6 . The $\mathrm{C} / \mathrm{N}$ ratios were first $70.27,56.19$ and 73.59 for treatments of agricultural wastes $+10 \%$ cow manure; agricultural wastes $+10 \%$ poultry manure and agricultural wastes $+10 \%$ mixture of camel and sheep manure, respectively.
As the result of the changes in the amount of nitrogen and the loss of organic carbon during composting process, a progressive narrowing in the $\mathrm{C} / \mathrm{N}$ ratios of the composted materials was observed reaching to 18.76 , 15.68 and 18.65 in respective order for treatments of agricultural wastes $+10 \%$ cow manure; agricultural wastes $+10 \%$ poultry manure and agricultural wastes $+10 \%$ mixture of camel and sheep manure, respectively. The changes in $\mathrm{C} / \mathrm{N}$ ratio could be taken as evidence of the degradation rate of the organic materials and the maturity of compost. These results are in line with those of Abdelhamid et al. (2004) who stated that, when $\mathrm{C} / \mathrm{N}$ value is around or below 20, it could be considered satisfactory. Khalil et al. (2001) demonstrated that the $\mathrm{C} / \mathrm{N}$ ratio of mature compost should ideally be about 10 but this is hardly ever achievable due to the presence of recalcitrant organic compounds, or materials which resist decomposition due to their physical or chemical properties. Some other authors reported that a $\mathrm{C} / \mathrm{N}$ ratio below 20 is an indicative of acceptable maturity. However, Moldes et al. (2007) stated that compost might be considered mature when $\mathrm{C} / \mathrm{N}$ ratio is approximately 17 or less, unless lingocellulolytic materials remain. 


\section{Macronutrients}

The quantity and form of $\mathrm{N}$ in particular, present in manure or compost is important in shaping the quality of the material and for its agronomic uses and are increasingly more often defined in compost specification (Lasaridi et al., 2006; Moldes et al., 2007). Definitely, the macronutrients $\mathrm{N}, \mathrm{P}$ and $\mathrm{K}$ are the most consumed elements by plants at the all stages of growth. The concentrations of NPK were increased during the composting process in all treatments (Table 7). Generally, the increase in total NPK during composting may have been due to the net loss of dry mass as loss of part of organic $\mathrm{C}$ as $\mathrm{CO}_{2}$. Moreover, total $\mathrm{N}$ can also be increased by the activities of associative $\mathrm{N}$-fixing bacteria at the end of composting process (Abdelhamid et al., 2004). These results are in similar with those obtained by different authors (Abd El-Maksoud et al., 2001, 2002; Kaviraj, 2003; Eida, 2007).

\section{Micronutrients}

It was seen that the Fe content was higher than the other elements in all treatments (Table 7). Conversely, the other three elements, $\mathrm{Mn}, \mathrm{Zn}$ and $\mathrm{Cu}$ recorded moderate increases until the maturity stage. Thus, composting can concentrate micronutrients (Zorpas et al., 2002). Micronutrients in poultry manure treatment were higher than the other manures at initial and end of composting.

\section{CONCLUSION}

The mixture of camel and sheep manure can be used as microbial activation to fasting decomposition process of composting the agricultural waste organic materials with caution of the toxicity of salts.

\section{REFERENCES}

Abdel-Aziz RA, Al-Barakah FN (2005). Composting technology and impact of compost on soil biochemical properties. Arab Gulf J. Sci. Res. 23(2):80-91.

Abd El-Maksoud HK, Azzazy MA, Abdel-Aziz RA, Saber M (2001). Biotransformation of organic fraction of municipal solid waste to compost and its manural effect on wheat growth. Egypt. J. Soil Sci. 39(3):8-14 .

Abd El-Maksoud HK, Azazy M, Abdel-aziz RA (2002), Biotransformation of the organic fraction of municipal solid waste to compost and its manural effect on wheat straw. Egypt. J. Soil Sci. (2):267-275

Abdelhamid TM, Horiuchi T, Oba S (2004). Composting of rice straw with oilseed rape cake and poultry manure and its effects on faba bean (Vicia faba L.) growth and soil properties. Bioresour. Technol. 93:183-189

Abo-Sedera, S (1995). Biological and chemical studies on organic wastes decomposition. Ph. D. Thesis, Faculty of Agriculture, AlAzhar University, Cairo, Egypt.

Agnew JM, Leonard JJ (2003). The physical properties of compost. Compost Sci. Util. 1:238-264.
Allen ON (1982). Experiments in Soil Bacteriology. Ins. Ed. Burgess Publ. USA.

AOAC (1970). Official Methods of Analysis of the Association of Official Agriculture Chemists. $11^{\text {th }} \mathrm{ed}$. Washington.

Ayyobi H, Peyvast GH, Olfati JA (2013). Effect of vermicompost and vermicompost extract on oil yield and quality of peppermint (Mentha piperita L.). J. Agric. Sci. 58(1):51-60.

Ayyobi H, Hassanpour E, Alaqemand S, Fathi S, Olfati JA, Peyvast Gh (2014). Vermicompost leachate and vermiwash enhance French dwarf bean yield than vermicompost does. Int. J. Veg. Sci. 20(1):2127.

Bhandari AL, Ladha JK, Pathak H, Padre AT, Dawe D, Gupta RK (2002). Yield and soil nutrient changes in a long-term rice-wheat rotation in India. Soil Sci. Soc. Am. J. 66:162-170.

Chen Y, Inbar Y, Hadar Y (1988). Composted agricultural wastes as potting media for ornamental plants. Soil Sci. 145:298-303.

Cottenie AM, Verlo L, Kjekens, Camerlynch R (1982). Chemical Analysis of Plant and Soil. Laboratory of Analytical Agro chemistry. State Univ. Gent, Belgium. No. 42:280-284.

Das K, Keener HM (1997). Moisture effect on compaction and permeability in composts. J. Environ. Eng. 123:275-281.

Dawe D, Dobermann A, Ladha JK, Yadav RL, Lin B, Gupta RK, Lal P, Panaullah G, Sarlam O, Singh Y, De Bertoldi M, Vallini G, Pera A, Zucconi F (1982). Comparison of three windrow compost systems. Biocycle 23:45-50.

de Bertoldi M, Vallini G, Pera A (1983). The biology of composting: a review. Waste Manage. Res. 1, 157-176.

Dick RP (1992). A review: long-term effects of agricultural systems on soil biochemical and microbial parameters. Agric. Ecosyst. Environ. 40:25-36.

Difco (1966). "Difco Manual of Dehydrated Culture Media and Reagents of Microbiological and Clinical Laboratory Procedures". $10^{\text {th }}$ ed. Difco Lab. Inc. Detroit, L, Michigan. USA.

Duplessis GL, MacKenzie FA (1983). Effects of leonardite applications on phosphorus availability and corn growth. Can. J. Soil Sci. 63:749751.

Edmeades DC (2003). The long-term effects of manures and fertilizers on soil productivity and quality: a review. Nutr. Cycling Agro Ecosyst. 66:165-180.

El-Meniawy MA (2003). Microbiological Studies on the Production of Non-Traditional Animal Feed from Agricultural Wastes. M. Sc. Thesis, Faculty of Agriculture, Al- Azhar University, Cairo, Egypt.

Eida MF (2007). Application of Biological Farming Principals for Producing Safe Vegetable Crops. M. Sc. Thesis, Faculty of Agriculture, Kafrelsheikh University.

Finstein MS, Miller FC, Strom PF (1986). Waste treatment composting as a controlled system. Biotechnol. 8:363-398.

Gajalakshmi S, Abbasi SA (2008). Solid waste management by composting: state of the art. Crit. Rev. Environ. Sci. Technol. 38:311400

Gutieŕrez-Miceli FA, Santiago-Borraz J, Molina JAM, Nafate CC, Abud-Archila M, Llaven MAO, Rincoń-Rosales R, Dendooven L (2007). Vermicompost as a soil supplement to improve growth, yield and fruit quality of tomato (Lycopersicum esculentum). Biores Technol. 98:2781-2786.

Haug RT (1993). The Practical Handbook of Compost Engineering. Lewis Publishers, Boca Raton, FL.

Jiang D, Hengsduk H, Dai TB, De Boer W, QI J, Cao WX (2006). Long-term effects of manure and inorganic fertilizers on yield and soil fertility for a winter wheat-maize system in Jiangsu, China. Pedosphere 16:25-32.

Kaviraj SS (2003). Municipal solid waste management through vermicomposting employing exotic and local species of earthworms. Bioresour. Technol. 90:169-173.

Khalil Al, Beheary MS, Salem EM (2001). Monitoring of microbial populations and their cellulolytic activities during the composting of municipal solid wastes. World J. Microbiol. Biotechnol. 17:155-161.

Khan HZ, Malik MA, Saleem MF (2008). Effect of rate and source of organic material on the production potential of spring maize (Zea mays L.). Pak. J. Agric. Sci. 45:40-43.

Ladha JK, Dawe D, Pathak H, Padre AT, Yadav RL, Singh B, Singh Y, Singh Y, Singh P, Kundu AL, Sakal R, Ram N, Regmi AP, Gam 
SK, Bhandari AL, Amin R, Yadav CR, Bhattarai EM, Das S, Aggarwal HP, Gupta RK, Hobbs PR (2003). How extensive are yield declines in long term rice-wheat experiments in Asia? Field Crops Res. 81:159-180.

Lasaridi K, Protopapa I, Kotsou M, Pilidis G, Manios T, Kyriacou A (2006). Quality assessment of composts in the Greek market: The need for standards and quality assurance. J. Environ. Manage. 80:58-65.

Malik MA, Ansar M, Zahoor F, Ahmad I (2006). Effect of organic and inorganic fertilizers on fodder yield of maize and its subsequent effect on soil. Pak. J. Agric. Eng. Vet. Sci. p. 22.

Miller FC (1992). Composting as a process based on the control of ecologically selective factors. In: Metting, F.B., Jr. (Ed.), Soil Microbial Ecology, Applications in Agricultural and Environmental Management. Marcel Dekker, Inc., New York, pp. 515-544.

Moldes A, Cendon Y, Barral MT (2007). Evaluation of municipal solid waste compost as a plant growing media component, by applying mixture design. Bioresour. Technol. 98:3069-3075.

Moss BR, Reeves DW, Lin JC, Torbert HA, McElhenney WH, Mask P, Kezar W (2001). Yield and quality of three corn hybrids as affected by broiler litter fertilization and crop maturity. Anim. Feed Sci. Technol. 94:43-56.

Noguerira WA, Nogueira FN, Devens DC (1999). Temperature and $\mathrm{pH}$ control in composting of coffee and agricultural wastes. Water Sci. Technol. 40(1):113-119.

Olfati JA, Peyvast GH, Nosrati-Rad Z, Saliqedar F, Rezaie F (2009). Application of municipal solid waste compost on lettuce yield. Int. J. Veg. Sci. 15(2):168-172.

Page AL, Miller RH, Keeney DR (1982). Methods of Soil Analysis: $\Pi$. Chemical and Microbiological Properties $2^{\text {nd }}$ edition. Agronomy V. 9. ASA, SSSA Publishing, Madison, WI, p. 1159.

Paustian K, Collins HP, Paul EA (1997). Management controls on soil carbon. In Soil Organic Matter in Temperate Agroecosystems (Eds E. A. Paul, K. Paustian, E. T. Elliot \& C. V. Cole), Boca Raton, FL: CRC Press. pp. 15-49.

Peyvast GH, Olfati JA, Ramezani-Kharazi P, Tahernia S, Shabani H (2008a). Effect of organic fertilizer on nitrate accumulation by vegetables. Hortic Environ. Biotechnol. 49(1):58-62.

Peyvast GH, Ramezani Kharazi P, Tahernia S, Nosratierad Z, Olfati JA (2008b). Municipal solid waste compost increased yield and decreased nitrate amount of broccoli (Brassica oleracea var. Italica). J. Appl. Hortic. 10(2):129-132.

Peyvast GH, Sedghi Moghaddam M, Olfati JA (2007). Effect of municipal solid waste compost on weed control, yield and some quality indices of green pepper (Capsicum annuum L.). Biosci. Biotechnol. Res. Asia 4(2):449-456.

Peyvast GH, Olfati JA, Madeni S, Forghani A (2008c). Effect of vermicompost on the growth and yield of spinach (Spinacia oleracea L.). Food Agric. Environ. 16(1):110-113.

Peyvast GH, Olfati JA, Madeni S, Forghani A, Samizadeh H (2008d). Vermicompost as a soil supplement to improve growth and yield of parsley. Int. J. Veg. Sci. 14(2):82-92.

Radwan SMA, Awad NM (2002). Effect of soil amendments with various organic wastes with multi-biofertilizers on peanut plants in sandy soil. J. Agric. Sci. Mansoura Univ. 27(5):3485-3494.

Recep İrfan N, Alpaslan K, İlker I, Ahmet D, Veyis T (2014). Effects of different organic materials on forage yield and quality of silage maize (Zea mays L.) Turkish J. Agric. For. 38:23-31.

Regmi AP, Ladha JK, Pathak H, Pasuquin E, Bueno C, Dawe D, Hobbs PR, Joshy D, Maskey SL, Pandey SP (2002). Yield and soil fertility trends in a 20 -year rice-rice-wheat experiment in Nepal. Soil Sci. Soc. Am. J. 66:857-867.
Richard TL, Hamelers HVM, Veeken AHM, Silva T (2002). Moisture relationships in composting processes. Compost Sci. Util. 10:286302.

Richards IR, Turner IDS, Wallace PA (1999). Manure and fertilizer contributions to soil mineral nitrogen and the yield of forage maize. Nutr. Cycl. Agroecosyst. 55:175-185.

Ryckeboer J, Mergaert J, Coosemans J, Deprins K, Swings J (2003). Microbiological aspects of biowaste during composting in a monitored compost bin. J. Appl. Microbiol. 94:127-137.

Saleque MA, Abedin MJ, Bhuiyan NI, Zaman SK, Panaullah GM (2004). Long-term effects of inorganic and organic fertilizer sources on yield and nutrient accumulation of lowland rice. Field Crops Res. 86:53-65.

Sarkar S, Singh SR, Singh RP (2003). The effect of organic and inorganic fertilizers on soil physical condition and the productivity of a rice-lentil cropping sequence in India. J. Agric. Sci. Cambridge 140:419-425.

Shabani H, Peyvast GH, Olfati JA, Ramezani KP (2011). Effect of municipal solid waste compost on yield and quality of eggplant. Comun. Sci. 2(2):85-90.

Stentiford EI (1996). Composting control: principles and practice. In the Science of Composting, Part 1, Edt. M. de bertoldi, P. Sequi, B. lemmes and T. Papi, pp. 29-59. Blackie, Glasgow.

TMECC (2002). Test methods for the examination of composting and composts. ed. Wayne Thompson. The US Composting Council. US Government printing office.

Yadav RL, Dwivedi BS, Pandey PS (2000a). Rice-wheat cropping system: assessment of sustainability under green manuring and chemical fertilizer inputs. Field Crops Res. 65:15-30.

Yadav R L, Dwivedi BS , Prasad K, Tomar OK, Shurpall NJ, Pandey PS (2000b). Yield trends, and changes in soil organic- $C$ and available NPK in a long-term rice-wheat system under integrated use of manures and fertilizers. Field Crops Res. 68:219-246.

Yadvinder S, Bijay S, Ladha JK, Khind CS, Gupta RK, Meelu OP, Pasuquin E (2004). Long-term effects of organic inputs on yield and soil fertility in the rice-wheat rotation. Soil Sci. Soc. Am. J. 68:845853.

Vance A (1997). Biological fixation of $\mathrm{N}_{2}$ for ecology and sustainable agriculture, Spring- Verlag, p. 179.

Wallace PA (2003). Compost Use in Agriculture, EB Nationwide.

Zakarya IA, Khalib SNB, Ramzi NM (2018). Effect of $\mathrm{pH}$, temperature and moisture content during composting of rice straw burning at different temperature with food waste and effective microorganisms. E35 .Wed. conferences. 34:02019. (http://doi.orgl 10.10651/e3secof/20183462019).

Zorpas AA, Dimitris A, Panagiotios K, Maria H, Giovannis Z (2002). Compost quality and use from sewage sludge, organic fraction of municipal solid waste and natural zeolite-clinoptilolite. In: Venglovsky, J., Greserova, G. (Eds.), RAMIRAN $200210^{\text {th }}$ International Conference Hygiene Safety, Strbske Pleso, High Tatras, Slovak Republic, May 14-18, pp. 381-389.

http://www.sciencewebpublishing.net/jacr 